\title{
Belnapia moabensis gen. nov., sp. nov., an alphaproteobacterium from biological soil crusts in the Colorado Plateau, USA
}

Correspondence Ferran Garcia-Pichel ferran@asu.edu

\author{
Gundlapally S. N. Reddy, Moria Nagy and Ferran Garcia-Pichel \\ School of Life Sciences, Arizona State University, Main Campus, Tempe, AZ 85287-4501, \\ USA
}

\begin{abstract}
Strain $\mathrm{CP} 2 \mathrm{C}^{\top}$ was isolated from biological soil crusts in the Colorado Plateau, USA. The isolate was aerobic, facultatively fermentative, Gram-negative, non-motile and red-pigmented (due to the presence of carotenoids), but did not contain bacteriochlorophyll a. The strain tested positive for catalase, oxidase and urease and was negative for lysine and ornithine decarboxylases and arginine dihydrolase. The major fatty acids present were $\mathrm{C}_{18: 1} \omega 7 \mathrm{c}$ and $\mathrm{C}_{16 \text { : } 0}$. It had a high DNA G + C content of 75 mol\%. Comparisons of $16 S$ rRNA gene sequences identified bacteriochlorophyll a-producing strains of Paracraurococcus ruber (94.9\%), Craurococcus roseus (92.2\%) and Roseococcus thiosulfatophilus (92.3\%), as well as non-bacteriochlorophyll a-producing bacteria Muricoccus roseus (94.9\%), Roseomonas gilardii $(94.2 \%)$ and Roseomonas mucosa (93.8\%), as the bacteria most closely related to strain $\mathrm{CP} 2 \mathrm{C}^{\top}$. Phylogenetically, $\mathrm{CP} 2 \mathrm{C}^{\top}$ was placed roughly equidistantly from the above organisms. Based on its phylogenetic placement and morphological and physiological characteristics, strain $\mathrm{CP} 2 \mathrm{C}^{\top}$ is assigned to a new genus in the $\alpha-1$ subgroup of the Proteobacteria, for which the name Belnapia gen. nov. is proposed. Strain CP2C ${ }^{\top}\left(=\right.$ ATCC BAA-1043 ${ }^{\top}=$ DSM $\left.16746^{\top}\right)$ is proposed as the type strain of the type species of this genus, with the name Belnapia moabensis gen. nov., sp. nov.
\end{abstract}

Biological soil crusts (BSCs) are notoriously slow-growing microbial communities formed by living organisms and their by-products in the top centimetres of the soil, creating a crust of soil particles bound together by organic materials (Belnap, 1993). BSCs are thought to contribute to a number of processes in the environment, especially to those that occur at the land surface or soil-air interface. These include soil stability, erosion resistance, atmospheric $\mathrm{N}_{2}$ fixation, nutrient contributions to plants, soil-plant-water relations, infiltration, seedling germination and plant growth (Belnap \& Gardner, 1993; Belnap, 2002; Johnson et al., 2005). They are particularly common in semiarid and arid environments throughout the world (Belnap, 1994). BSCs are dominated by cyanobacteria, lichens and sometimes by mosses or eukaryotic algae as primary producers (Belnap et al., 2001).

Abbreviations: Bchl a, bacteriochlorophyll a; BSC, biological soil crust; SEM, scanning electron microscopy.

The GenBank/EMBL/DDBJ accession number for the 16S rRNA gene sequence of strain $\mathrm{CP}^{\mathrm{C}} \mathrm{C}^{\top}$ is AJ871428.

A 165 rRNA gene sequence similarity matrix, a comparison of nucleotides in the 16S rRNA gene sequence between Belnapia moabensis and related species and UPGMA and maximum-parsimony phylogenetic trees are available as supplementary material in IJSEM Online.
Bacteria and fungi are the major heterotrophic components, but little is known about their taxonomic placement. Recent survey studies from various geographical settings (L. M. Nagy, P. Alejandro and F. Garcia-Pichel, unpublished; G. S. N. Reddy and F. Garcia-Pichel, unpublished; Smith et al., 2004) point to the dominance of poorly known and probably novel taxa of Actinobacteria, Proteobacteria, 'Bacteroidetes' and low-DNA G + C-content Gram-positive bacteria. Attempts at cultivation and characterization of these bacteria are limited to Dyadobacter crusticola, belonging to the 'Bacteroidetes' (Reddy \& Garcia-Pichel, 2005). In the present study, we characterized a BSC isolate belonging to the Alphaproteobacteria using polyphasic taxonomic methods. The phenotypic, chemotaxonomic and phylogenetic analyses established that the isolate does not belong to any of the genera described so far. Therefore, it was classified under a new genus, Belnapia gen. nov., with the name Belnapia moabensis sp. nov.

Strain $\mathrm{CP} 2 \mathrm{C}^{\mathrm{T}}$ was isolated from a BSC sample near the town of Moab (UT, USA), in the Colorado Plateau ( $38^{\circ} 34^{\prime} 984^{\prime \prime} \mathrm{N}$ and $109^{\circ} 31^{\prime} 451^{\prime \prime} \mathrm{W}$; collected between 20 and 22 May 2003). The physico-chemical characteristics of the sampling site have been described by Garcia-Pichel et al. (2003) and Johnson et al. (2005). Initially, a $0 \cdot 5 \mathrm{~g}$ sample was suspended 
in Ringer's solution $\left(9 \mathrm{~g} \mathrm{NaCl}, 0.042 \mathrm{~g} \mathrm{KCl}, 0.025 \mathrm{~g} \mathrm{CaCl}_{2}\right.$ and $100 \mathrm{ml}$ distilled water) and shaken for $30 \mathrm{~min}$. The suspension was allowed to settle and $100 \mu$ supernatant was plated on PGY-BG11 agar (Reddy \& Garcia-Pichel, 2005) and incubated in the dark at room temperature. A redpigmented colony was isolated, purified and maintained on PGY-BG11.

Cell morphology was studied using light microscopy and scanning electron microscopy (SEM). For SEM, cells were mounted on Formvar-coated copper grids and negatively stained with $0.5 \%(\mathrm{w} / \mathrm{v})$ uranyl acetate. Grids were examined in a JEM-1010 SEM (JEOL) operated at $60 \mathrm{kV}$. Growth at different temperatures was determined using $10 \times$ PGY-BG11 medium. For growth at different $\mathrm{pH}$, the components of $10 \times$ PGY-BG11 were dissolved in $0 \cdot 1 \mathrm{M}$ phosphate buffer with $\mathrm{pH}$ values ranging from 5 to 12 . Tolerance to salt was observed by the addition of $\mathrm{NaCl}$ $(0 \cdot 5-6 \%$, final concentration) in $10 \times$ PGY-BG11. For all biochemical tests, cells were grown on $10 \times$ PGY-BG11. Catalase activity was determined by bubble production in $30 \%(\mathrm{v} / \mathrm{v})$ aqueous hydrogen peroxide solution. Oxidase activity was tested by oxidation of $1 \%(\mathrm{w} / \mathrm{v})$ tetramethyl- $p$ phenylenediamine (Merck) to a deep purple or blue colour. Nitrate reduction, hydrolysis of aesculin, casein, starch, Tween 80, urea and gelatin and various enzyme activities were determined on $10 \times$ PGY-BG11 according to previously described methods (Lanyi, 1987; Smibert \& Krieg, 1994). Carbon assimilation tests were performed by adding each carbon compound, at a final concentration of $0.5 \%$, to a base of BG11 medium lacking citric acid (Reddy \& Garcia-Pichel, 2005). Antibiotic susceptibility was assayed with antibiotic discs, according to the Kirby-Bauer method (Becton Dickinson Microbiological systems). For testing aerobic and anaerobic photoautotrophic growth, culture was inoculated into liquid and streaked onto agarized BS-V (Saitoh \& Nishimura, 1996) or PNP media at $\mathrm{pH} 6.8$ and incubated in the light at room temperature. PNP contained, $\left(\mathrm{l}^{-1}\right), 0.5 \mathrm{~g} \mathrm{NaCl}, 0 \cdot 4 \mathrm{~g} \mathrm{MgCl}_{2} \cdot 6 \mathrm{H}_{2} \mathrm{O}, 0 \cdot 1 \mathrm{~g} \mathrm{CaCl}_{2} \cdot 2 \mathrm{H}_{2} \mathrm{O}$, $0.2 \mathrm{~g} \mathrm{KH}_{2} \mathrm{PO}_{4}, 0.05 \mathrm{~g} \mathrm{KCl}, 0.5 \mathrm{~g} \mathrm{Na}_{2} \mathrm{HCO}_{3}, 2.38 \mathrm{~g}$ HEPES, $1 \mathrm{ml} 1000 \times$ vitamin solution and $1 \mathrm{ml}$ trace element solution. The vitamin solution contained, $\left(100 \mathrm{ml}^{-1}\right) ; 5 \mathrm{mg}$ biotin, $100 \mathrm{mg}$ thiamin, $100 \mathrm{mg}$ nicotinic acid, $50 \mathrm{mg}$ aminobenzoic acid, $1 \mathrm{mg}$ vitamin $B_{12}, 50 \mathrm{mg}$ calcium pantothenate, $50 \mathrm{mg}$ pyridoxine hydrochloride, $50 \mathrm{mg}$ folic acid and $20 \mathrm{mg}$ trisodium EDTA. The composition of the trace element solution used was as follows, $\left(1^{-1}\right)$, $10 \mathrm{mg} \mathrm{ZnSO}_{4} \cdot 7 \mathrm{H}_{2} \mathrm{O}, 3 \mathrm{mg} \mathrm{MnCl}_{2} \cdot 4 \mathrm{H}_{2} \mathrm{O}, 30 \mathrm{mg} \mathrm{H}_{3} \mathrm{BO}_{3}$, $20 \mathrm{mg} \mathrm{CoCl} \cdot 6 \mathrm{H}_{2} \mathrm{O}, 1 \mathrm{mg} \mathrm{CuCl} 2 \cdot 2 \mathrm{H}_{2} \mathrm{O}, 2 \mathrm{mg} \mathrm{NiCl} \cdot 6 \mathrm{H}_{2} \mathrm{O}$ and $3 \mathrm{mg} \mathrm{Na} 2 \mathrm{MoO}_{4}$. Anaerobic conditions were achieved in GasPak jars with GasPak Plus anaerobic system envelopes (Becton Dickinson). The head space of the jars contained $\mathrm{CO}_{2}$ and $\mathrm{H}_{2}$. The ability of the culture to fix nitrogen was tested using BG11 medium without nitrate $\left(\mathrm{BG}_{1} 1^{\circ}\right)$, but containing $0.5 \%$ glucose $(\mathrm{w} / \mathrm{v})$ as the carbon source.

Quantitative analysis of whole-cell fatty acids was performed by growing strain $\mathrm{CP} 2 \mathrm{C}^{\mathrm{T}}$ on tryptic soy agar medium at $25^{\circ} \mathrm{C}$. Fatty acid methyl esters were prepared according to the instructions for the Microbial Identification System (Microbial ID) and analysed using gas chromatography/ mass spectrometry. Lipids were extracted and analysed according to Suresh et al. (2004). Respiratory quinones were extracted and analysed as described by Komagata \& Suzuki (1987). For pigment characterization, cells were grown on $10 \times$ PGY-BG11 plates, scraped off the surface, suspended in $50 \mathrm{mM}$ phosphate buffer or methanol and sonicated for $10 \mathrm{~min}$ at $4{ }^{\circ} \mathrm{C}$. The suspension was centrifuged at 10000 r.p.m. to remove unbroken cells. Absorption spectra were recorded for the supernatant with a Shimadzu UV1601 spectrophotometer from 200 to $1100 \mathrm{~nm}$. For in vivo pigment characterization, cells were grown aerobically under dark and light conditions at room temperature, suspended in $50 \%$ glycerol containing $0.04 \%$ sodium thioglycollate (to prevent oxidation of pigments) and the spectrum was recorded using $50 \%$ glycerol containing $0.04 \%$ sodium thioglycollate as a blank (Bryantseva et al., 2000). The pigments were further resolved on HPLC with online diode array detection using a u-Bondapack C18 reverse-phase column. The solvent system employed was a gradient of $1 \mathrm{M}$ ammonium acetate/methanol (1:4) (solvent A) to methanol (solvent B). The gradient used was $0 \%$ solvent $\mathrm{A}$ at time 0 to $5 \mathrm{~min}$ and, at $40 \mathrm{~min}, 100 \%$ solvent $\mathrm{B}$. The flow rate used was $1 \mathrm{ml} \mathrm{min}^{-1}$ and the detector was set at $519 \mathrm{~nm}$.

DNA was isolated and the $\mathrm{G}+\mathrm{C}$ content (mol\%) was determined according to Reddy et al. (2000). A mean value from two independent experiments was calculated; the variation between the experiments was less than $2 \%$. PCR amplification of approximately $1.5 \mathrm{~kb}$ of the puf gene was achieved and it was sequenced using the primer set PULM $\left(5^{\prime}\right.$-KTTCGACTTCTGGGTSGG-3') and PULM $_{2}$ (5'CCCATSGTCCAGCGCCAG-3') (Alarico et al., 2002) and a strain of Rhodopseudomonas isolated in our lab was used as a control.

For 16S rRNA gene sequencing, DNA was prepared using the MoBio microbial DNA isolation kit (MoBio Laboratories). Approximately $1.5 \mathrm{~kb}$ of the $16 \mathrm{~S}$ rRNA gene was amplified using primers GM3F (5'-AGAGTTTGATCMTGGC-3'; Nübel et al., 1997) and 16S2 (5'-ACGGCTACCTTGTTACGACTT-3'; Reddy et al., 2000). Fragments of around $1500 \mathrm{bp}$ were purified from agarose gels with a Qiagen kit and sequenced using the primers 907R (5'-CCGTCAATTCCTTTRAGTTT-3'; Nübel et al., 1997), pC* (5'CCCACTGCTGCCTCCCGTAG-3'), pE (5'-AAACTCAAAGGAATTGACGG-3') and 16S2 (Reddy et al., 2000). The phylogenetic position of $\mathrm{CP} 2 \mathrm{C}^{\mathrm{T}}$ was ascertained by aligning the partial sequence of the $16 \mathrm{~S}$ rRNA gene containing 1453 nucleotides [nucleotides 6-1513 according to the Escherichia coli 16S rRNA (J 01695) numbering], with closely related sequences belonging to the Alphaproteobacteria, using the CLUSTAL $\mathrm{W}$ program (Thompson et al., 1994). These sequences were included after the initial BLAST search. Pairwise evolutionary distances were computed 
using the DNADIST program with the Kimura two-parameter model, as developed by Kimura (1980). Phylogenetic trees were constructed using three tree-making algorithms, neighbour-joining, unweighted pair group method with arithmetic averages (UPGMA) and DNA parsimony program (DNAPARS), from the MEGA2 package (Kumar et al., 2001). Clade stability in the phylogenetic tree was assessed by analysing 1000 replicates of the dataset.

Strain $\mathrm{CP} 2 \mathrm{C}^{\mathrm{T}}$ forms colonies that are $1-2 \mathrm{~mm}$ in diameter, convex, rough and red-pigmented with rounded margins.

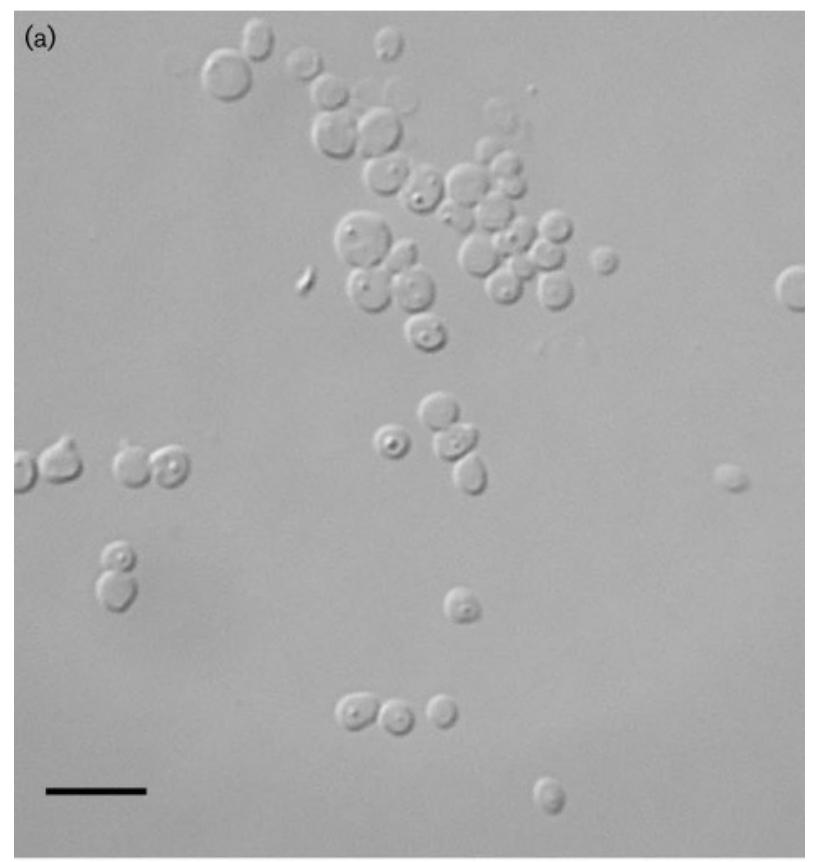

(b)

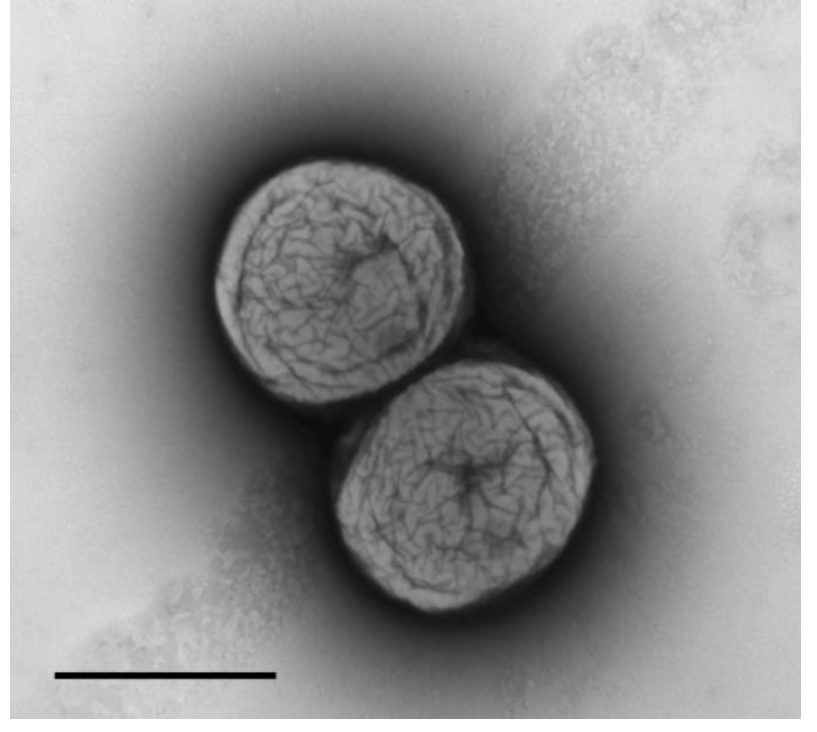

Fig. 1. Phase-contrast (a) and SEM (b) micrographs of cells of Belnapia moabensis CP2C $\mathrm{C}^{\top}$. Bars, (a) $3 \mu \mathrm{m}$; (b) $1 \mu \mathrm{m}$.
Cells are coccoid, occur singly, in pairs and in groups (Fig. 1a, b) and are non-motile. They are catalase-, oxidaseand urease-positive, have $\mathrm{C}_{18: 1} \omega 7 c, \mathrm{C}_{16: 0}, \mathrm{C}_{18: 1} 2-\mathrm{OH}$ and $\mathrm{C}_{16: 1} \omega 7 / \mathrm{C}_{15: 0}$ iso $2-\mathrm{OH}$ as the major fatty acids and have a DNA G $+\mathrm{C}$ content of $75 \mathrm{~mol} \%$. Other characteristics of $\mathrm{CP} 2 \mathrm{C}^{\mathrm{T}}$ are given in the species description. $\mathrm{CP} 2 \mathrm{C}^{\mathrm{T}}$ did not grow phototrophically under aerobic or anaerobic conditions on PNP or BS-V media (Saitoh \& Nishimura, 1996). Methanolic (Fig. 2) or buffer extracts of the pigments or pigments recorded in vivo did not show any peaks characteristic of bacteriochlorophylls. In addition, PCR amplification of puf genes, using specific primers (Alarico et al., 2002), resulted in no product, indicating that the biosynthetic genes for bacteriochlorophyll $a(\mathrm{Bchl} a)$ are absent in $\mathrm{CP} 2 \mathrm{C}^{\mathrm{T}}$.

The pigment extracts were resolved into eight different peaks on HPLC; all of them exhibited absorption spectra characteristic of carotenoids. The major carotenoid had absorption maxima at 460, 490 and $520 \mathrm{~nm}$.

The 16S rRNA gene sequence of $\mathrm{CP} 2 \mathrm{C}^{\mathrm{T}}$ contains all of the signature nucleotides that are characteristic of the Alphaproteobacteria and the strain could be grouped in the $\alpha-1$ subgroup (Woese, 1987). A BLAST sequence similarity search, based on the 16S rRNA gene sequence, identified Paracraurococcus ruber (Saitoh et al., 1998), Muricoccus roseus (Kämpfer et al., 2003), Roseomonas gilardii (Rihs et al., 1993), Roseomonas mucosa (Han et al., 2003), Rubritepida flocculans (Alarico et al., 2002) and Roseococcus thiosulfatophilus (Yurkov et al., 1994) as related organisms. The evolutionary distances, calculated using the Kimura-2 factorial model and based on 16S rRNA gene sequences, indicated that $\mathrm{CP} 2 \mathrm{C}^{\mathrm{T}}$ is related to Pcr. ruber $(94.9 \%), M$. roseus $(94 \cdot 9 \%)$, R. gilardii (94.2\%), R. mucosa $(93 \cdot 8 \%)$, Rsc. thiosulfatophilus (92.3\%), Teichococcus ludipueritiae (92.3\%), Crc. roseus (92.2\%), Rut. flocculans (92.2\%), Rpi. globiformis (91.5\%) and Acidiphilium cryptum (90.7\%) (see Supplementary Table S1 in IJSEM Online). As strain CP2C ${ }^{\mathrm{T}}$ exhibited a 16S rRNA gene sequence similarity of less than $97 \cdot 5 \%$ with all of these closely related species, $\mathrm{CP} 2 \mathrm{C}^{\mathrm{T}}$ does not represent a novel strain of any of these species

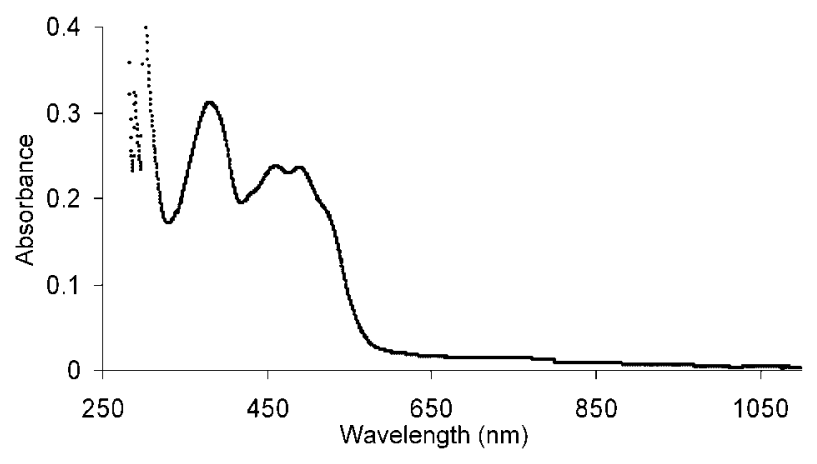

Fig. 2. Absorption spectrum of methanol extract of Belnapia moabensis CP2C ${ }^{\top}$. 
(Stackebrandt \& Goebel, 1994), but could represent a novel species belonging to one of the genera. A base-to-base comparison of 1447 nucleotides in the 16S rRNA gene sequences of strain $\mathrm{CP} 2 \mathrm{C}^{\mathrm{T}}$ and its relatives indicated a broad range of nucleotide variation: Pcr. ruber (80), M. roseus (83), R. gilardii (87), R. mucosa (94), Rsc. thiosulfatophilus (112), T. ludipueritiae (112), Crc. roseus (123), Rut.flocculans (120), Rpi. globiformis (137) and A. cryptum (144). In addition, CP2 $\mathrm{C}^{\mathrm{T}}$ exhibited differences of 47 nucleotides (Pcr. ruber) to 55 nucleotides ( $R$. mucosa and T. ludipueritiae) in nucleotides that are highly conserved among these genera. Further, there were 14 nucleotides, $\mathrm{T}$ (between 218 and 221), G (382), T (593), G (594), C (647), A (648), A (672), T (1135), G (between 1137 and 1138), A (1141), C (1144), G (1261), A (1267) and $\mathrm{T}(1276)$, and three deletions at positions 99, 1010 and after 1463 , that are present only in $\mathrm{CP} 2 \mathrm{C}^{\mathrm{T}}$ (numbering is with respect to the E. coli 16S rRNA gene sequence, J01695) (see Supplementary Table S2 in IJSEM Online). Thus, the phylogenetic signatures suggest that $\mathrm{CP} 2 \mathrm{C}^{\mathrm{T}}$ can be distinguished at a taxonomic rank higher than species, and probably at the genus level, from the other related species. In fact, some of the above genera have been distinguished mostly on differences at the phylogenetic level. For instance, the genus Paracraurococcus (Saitoh et al., 1998) is phenotypically different from Craurococcus only with respect to maximum growth temperature and hydrolysis of Tween 80 (Saitoh et al., 1998), but it showed sufficient differences in 16S rRNA gene sequence, having a similarity of only $94 \cdot 7 \%$, to warrant separation. Similarly, Muricoccus (Kämpfer et al., 2003) was delineated from Roseomonas (Rihs et al., 1993; Han et al., 2003) at a 16S rRNA gene sequence similarity of $95.9 \%$, though it exhibited differences only with respect to cell shape and fatty acids.

The topology of neighbour-joining and maximumparsimony trees (Fig. 3 and Supplementary Fig. S1b in IJSEM Online) placed $\mathrm{CP} 2 \mathrm{C}^{\mathrm{T}}$ roughly equidistant from strains containing $\mathrm{BChl} a$, (Pcr. ruber, Crc. roseus, Rut. flocculans and Rsc. thiosulfatophilus) and lacking BChl a (M. roseus, $R$. gilardii and $R$. mucosa). In UPGMA trees (Supplementary Fig. S1a in IJSEM Online), $C P 2 C^{\mathrm{T}}$ clustered with the BChl $a$-containing Pcr. ruber. The above results clearly indicate that the position of $\mathrm{CP} 2 \mathrm{C}^{\mathrm{T}}$ is sufficiently distinct and deeply rooted from the strains containing or lacking $\mathrm{Bchl} a$ to warrant the creation of a novel genus.

Apart from phylogenetic characteristics, the phenotypic properties of $\mathrm{CP} 2 \mathrm{C}^{\mathrm{T}}$ also suggest that the strain is quite different from its close relatives. For example, $\mathrm{CP} 2 \mathrm{C}^{\mathrm{T}}$ is different from Pcr. ruber at the genus level in that it does not contain BChl $a$, does not produce $\mathrm{H}_{2} \mathrm{~S}$ and contains significant levels of fatty acid $\mathrm{C}_{17: 1} \omega 7 c$ (Table 1). Additional differences are listed in Table 1. Strain $\mathrm{CP} 2 \mathrm{C}^{\mathrm{T}}$ is also closely related to $M$. roseus on the basis of rRNA gene sequence similarity (94.9\%; see Supplementary Table S1 in IJSEM Online). Both organisms lack BChl $a$, but differ in cell morphology (Table 1), a feature sufficient to differentiate them at the genus level (Yoon et al., 2001), and in the lack of

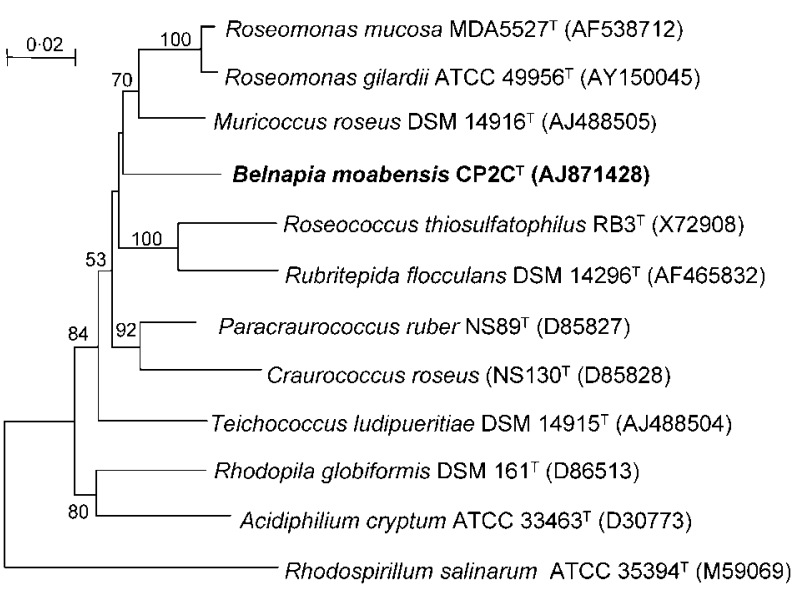

Fig. 3. Neighbour-joining tree based on 16S rRNA gene sequences (1453 bp) showing the phylogenetic relationship between Belnapia moabensis $\mathrm{CP}_{2} \mathrm{C}^{\top}$ and other related members of the Alphaproteobacteria. Bootstrap values (expressed as percentages of 1000 replications) greater than $50 \%$ are indicated at the nodes. Bar, 0.02 substitutions per nucleotide position.

lysine decarboxylase, ornithine decarboxylase and arginine dihydrolase activities (Table 1 ) and $\mathrm{C}_{12: 0}$ fatty acids. The neighbour-joining tree indicated that $\mathrm{CP} 2 \mathrm{C}^{\mathrm{T}}$ was most closely related to Rsc. thiosulfatophilus, a result further supported by in-depth 16S rRNA gene sequence comparisons of signature nucleotides (see Supplementary Table S2 in IJSEM Online). However, $\mathrm{CP} 2 \mathrm{C}^{\mathrm{T}}$ is different from Rsc. thiosulfatophilus in that it is non-motile, does not contain BChl $a$ and is a mesophile (Table 1). CP2 $\mathrm{C}^{\mathrm{T}}$ can be differentiated from the closely related species $R$. gilardii and $R$. mucosa on the basis of fatty acid content. $\mathrm{CP} 2 \mathrm{C}^{\mathrm{T}}$ had the highest DNA G $+\mathrm{C}$ content, $75 \mathrm{~mol} \%$, of all the bacteria used in the present comparison (which ranged from 61 to $71 \mathrm{~mol} \%$ ). Additional differentiating traits are listed in Table 1.

In conclusion, $\mathrm{CP} 2 \mathrm{C}^{\mathrm{T}}$ can be differentiated from the closest nine genera on the basis of phylogenetic signature sequences, the absence of Bchl $a$, fatty acid content, DNA $\mathrm{G}+\mathrm{C}$ content and physiology (Table 1 ). Since $\mathrm{CP} 2 \mathrm{C}^{\mathrm{T}}$ does not possess the generic characteristics of any of the nine closest genera, we suggest a novel genus to accommodate $\mathrm{CP} 2 \mathrm{C}^{\mathrm{T}}$, for which the name Belnapia gen. nov. is proposed. Strain $C P 2 C^{\mathrm{T}}$ represents the type strain of the type species of this genus, Belnapia moabensis sp. nov. Strain $\mathrm{CP} 2 \mathrm{C}^{\mathrm{T}}$ has several interesting physiological characteristics as it is oligotrophic, salt-sensitive (does not grow in presence of $0.5 \% \mathrm{NaCl}$ ), grows on $0.5 \%$ phenanthrene and can use oxalate as sole carbon source.

\section{Description of Belnapia gen. nov.}

Belnapia (Bel.na' pi.a. N.L. fem. n. Belnapia after J. Belnap, in honour of her contributions to the study of BSCs). 


\section{Table 1. Characteristics that differentiate Belnapia moabensis $\mathrm{CP}_{2} \mathrm{C}^{\top}$ from closely related organisms}

Taxa: 1, Belnapia moabensis CP2C ${ }^{\mathrm{T}}$; 2, Pcr. ruber NS89 ${ }^{\mathrm{T}}$ (data from Saitoh et al., 1998; Saitoh \& Nishimura, 1996); 3, Crc. roseus NS130 ${ }^{\mathrm{T}}$ (Saitoh et al., 1998; Saitoh \& Nishimura, 1996); 4, Rsc. thiosulfatophilus RB3 ${ }^{\mathrm{T}}$ (Yurkov et al., 1994); 5, R. gilardii ATCC 49956 (Rihs et al., 1993; Han et al., 2003); 6, R. mucosa MDA 5527 (Han et al., 2003); 7, M. roseus DSM 14916 ${ }^{\mathrm{T}}$ (Kämpfer et al., 2003); 8, T. ludipueritiae DSM $14915^{\mathrm{T}}$ (Kämpfer et al., 2003); 9, Rut. flocculans DSM $14296^{\mathrm{T}}$ (Alarico et al., 2002). -, Negative; +, positive; V, variable; W +, weakly positive; ND, not determined; s, susceptible; R, resistant; tr, trace; NK, not known.

\begin{tabular}{|c|c|c|c|c|c|c|c|c|c|}
\hline Characteristic & 1 & 2 & 3 & 4 & 5 & 6 & 7 & 8 & 9 \\
\hline \multicolumn{10}{|l|}{ Morphology } \\
\hline Cell shape & Cocci & Cocci & Cocci & Cocci & Cocci & Cocci & Short rods & Short rods & Short rods \\
\hline Motility & - & - & - & + & $\mathrm{V}$ & + & - & - & + \\
\hline Growth range $\left({ }^{\circ} \mathrm{C}\right)$ & $15-30$ & $20-42$ & $20-37$ & NK & $30-42$ & $25-42$ & $20-42$ & $20-42$ & $30-50$ \\
\hline Arginine dihydrolase & - & ND & ND & ND & - & ND & + & + & ND \\
\hline Bchl $a$ & - & + & + & + & - & - & - & - & + \\
\hline DNA G $+\mathrm{C}$ content $(\mathrm{mol} \%)$ & 75 & 71 & $70 \cdot 5$ & $70 \cdot 4$ & $67 \cdot 6$ & $66 \cdot 3$ & $68 \cdot 9$ & $65 \cdot 8$ & $70 \cdot 2$ \\
\hline $\mathrm{H}_{2} \mathrm{~S}$ production & - & + & + & $\mathrm{ND}$ & - & $\mathrm{ND}$ & - & - & $\mathrm{ND}$ \\
\hline Lipase & - & - & + & - & ND & ND & ND & ND & - \\
\hline \multicolumn{10}{|l|}{ Acid production from: } \\
\hline Arabinose & - & + & + & ND & ND & ND & - & - & ND \\
\hline Fructose & - & - & + & ND & ND & ND & ND & ND & ND \\
\hline Galactose & - & - & + & ND & ND & ND & ND & ND & ND \\
\hline Glucose & - & + & + & ND & ND & $\mathrm{ND}$ & - & - & ND \\
\hline Xylose & - & + & + & ND & - & $\mathrm{ND}$ & - & - & ND \\
\hline \multicolumn{10}{|l|}{ Utilization of carbon sources: } \\
\hline Acetate & - & - & - & + & ND & ND & + & + & - \\
\hline Adonitol & + & ND & ND & $\mathrm{ND}$ & ND & ND & - & - & $\mathrm{ND}$ \\
\hline Alanine & - & + & + & $\mathrm{W}+$ & $\mathrm{ND}$ & ND & - & - & $\mathrm{w}+$ \\
\hline Arabinose & - & + & + & - & ND & + & - & - & + \\
\hline Glutamic acid & - & + & + & $\mathrm{ND}$ & $\mathrm{ND}$ & $\mathrm{ND}$ & ND & $\mathrm{ND}$ & + \\
\hline Glycerol & - & + & + & ND & ND & ND & - & - & + \\
\hline Inositol & + & ND & ND & ND & $\mathrm{ND}$ & $\mathrm{ND}$ & - & - & ND \\
\hline Maltose & + & ND & ND & ND & $\mathrm{ND}$ & - & - & - & $\mathrm{ND}$ \\
\hline Mannitol & + & - & - & ND & $\mathrm{ND}$ & - & - & - & ND \\
\hline Mannose & + & + & + & - & $\mathrm{ND}$ & $\mathrm{ND}$ & - & - & - \\
\hline Methionine & + & - & - & ND & ND & $\mathrm{ND}$ & ND & ND & ND \\
\hline Proline & + & $\mathrm{ND}$ & $\mathrm{ND}$ & ND & $\mathrm{ND}$ & $\mathrm{ND}$ & - & - & ND \\
\hline Pyruvate & - & + & + & + & ND & $\mathrm{ND}$ & - & - & + \\
\hline Rhamnose & + & + & + & - & ND & $\mathrm{ND}$ & - & - & ND \\
\hline Ribose & + & + & + & $\mathrm{w}+$ & ND & $\mathrm{ND}$ & - & - & - \\
\hline Sorbitol & + & - & - & $\mathrm{ND}$ & $\mathrm{ND}$ & $\mathrm{ND}$ & - & - & $\mathrm{ND}$ \\
\hline Sorbose & + & + & ND & - & ND & ND & - & - & + \\
\hline Sucrose & + & $\mathrm{ND}$ & $\mathrm{ND}$ & $\mathrm{ND}$ & $\mathrm{ND}$ & $\mathrm{ND}$ & - & - & $\mathrm{ND}$ \\
\hline
\end{tabular}


Table 1. cont.

\begin{tabular}{|c|c|c|c|c|c|c|c|c|c|}
\hline Characteristic & 1 & 2 & 3 & 4 & 5 & 6 & 7 & 8 & 9 \\
\hline Trehalose & + & ND & ND & ND & ND & ND & $\mathrm{w}+$ & - & ND \\
\hline Xylose & + & + & + & $\mathrm{w}+$ & $\mathrm{ND}$ & ND & - & - & + \\
\hline \multicolumn{10}{|l|}{ Antibiotic sensitivity: } \\
\hline Gentamicin & s & ND & ND & $\mathrm{R}$ & $S$ & ND & ND & ND & ND \\
\hline Penicillin & s & ND & ND & $\mathrm{R}$ & $\mathrm{ND}$ & ND & ND & ND & ND \\
\hline Polymyxin B & $\mathrm{R}$ & ND & ND & S & $\mathrm{ND}$ & ND & ND & ND & ND \\
\hline Tetracycline & $\mathrm{R}$ & $\mathrm{ND}$ & $\mathrm{ND}$ & s & S & ND & ND & ND & ND \\
\hline Vancomycin & $\mathrm{R}$ & $\mathrm{ND}$ & $\mathrm{ND}$ & S & $\mathrm{ND}$ & ND & ND & ND & ND \\
\hline \multicolumn{10}{|l|}{ Fatty acid methyl esters ${ }^{\star}$} \\
\hline \multicolumn{10}{|l|}{ Saturated: } \\
\hline $\mathrm{C}_{12: 0}$ & - & $1 \cdot 0$ & - & $2 \cdot 3$ & - & - & $5 \cdot 0$ & - & $2 \cdot 5$ \\
\hline $\mathrm{C}_{14: 0}$ & - & $0 \cdot 6$ & $1 \cdot 5$ & - & - & - & $1 \cdot 0$ & $0 \cdot 9$ & $0 \cdot 3$ \\
\hline $\mathrm{C}_{16: 0}$ & $17 \cdot 02$ & $8 \cdot 7$ & $12 \cdot 5$ & $7 \cdot 6$ & $16 \cdot 93$ & $19 \cdot 53$ & $16 \cdot 6$ & $6 \cdot 9$ & $20 \cdot 0$ \\
\hline $\mathrm{C}_{18: 0}$ & $2 \cdot 04$ & $1 \cdot 3$ & 2 & $0 \cdot 7$ & $1 \cdot 15$ & $1 \cdot 16$ & $1 \cdot 0$ & - & $26 \cdot 6$ \\
\hline \multicolumn{10}{|l|}{ Branched: } \\
\hline $\mathrm{C}_{15: 0}$ iso & $0 \cdot 84$ & - & - & - & - & - & - & - & - \\
\hline \multicolumn{10}{|l|}{ Unsaturated: } \\
\hline $\mathrm{C}_{16: 1} \omega 7 c$ & $7 \cdot 67$ & $5 \cdot 8$ & $12 \cdot 7$ & $0 \cdot 9$ & $1 \cdot 3$ & $1 \cdot 23$ & $22 \cdot 0$ & $3 \cdot 3$ & $1 \cdot 2$ \\
\hline $\mathrm{C}_{16: 1} \omega 5 c$ & $1 \cdot 28$ & $0 \cdot 4$ & $1 \cdot 1$ & $0 \cdot 5$ & $0 \cdot 23$ & - & - & $\operatorname{tr}$ & - \\
\hline $\mathrm{C}_{17: 1} \omega 7 c$ & $3 \cdot 20$ & - & - & - & - & - & $2 \cdot 1$ & - & - \\
\hline $\mathrm{C}_{18: 1} \omega 7 c$ & $53 \cdot 78$ & $73 \cdot 4$ & $53 \cdot 2$ & $65 \cdot 1$ & $60 \cdot 64$ & $46 \cdot 55$ & $39 \cdot 2$ & $68 \cdot 3$ & $23 \cdot 4$ \\
\hline $\mathrm{C}_{18: 1} \omega 5 c$ & $1 \cdot 71$ & - & $0 \cdot 6$ & $1 \cdot 1$ & $0 \cdot 27$ & - & $0 \cdot 9$ & $\operatorname{tr}$ & $0 \cdot 5$ \\
\hline $\mathrm{C}_{18: 2} \omega 6,9 c / \mathrm{C}_{18: 0}$ ante & - & - & - & - & $0 \cdot 73$ & $0 \cdot 4$ & - & - & - \\
\hline \multicolumn{10}{|l|}{ Hydroxy: } \\
\hline $\mathrm{C}_{14: 0} 3-\mathrm{OH}$ & $2 \cdot 85$ & $0 \cdot 8$ & $1 \cdot 1$ & $3 \cdot 0$ & $0 \cdot 65$ & $0 \cdot 89$ & - & $\operatorname{tr}$ & $2 \cdot 3$ \\
\hline $\mathrm{C}_{16: 0} 2-\mathrm{OH}$ & - & - & - & - & - & $1 \cdot 24$ & - & - & $2 \cdot 7$ \\
\hline $\mathrm{C}_{16: 0} 3-\mathrm{OH}$ & $1 \cdot 41$ & - & - & - & $2 \cdot 86$ & $4 \cdot 13$ & - & - & - \\
\hline $\mathrm{C}_{18: 1} 2-\mathrm{OH}$ & $7 \cdot 61$ & $6 \cdot 2$ & $12 \cdot 3$ & $15 \cdot 5$ & $11 \cdot 26$ & $3 \cdot 82$ & $8 \cdot 8$ & $15 \cdot 1$ & $0 \cdot 7$ \\
\hline $\mathrm{C}_{18: 0} 3-\mathrm{OH}$ & $0 \cdot 58$ & $0 \cdot 6$ & $1 \cdot 8$ & $2 \cdot 4$ & - & - & $1 \cdot 0$ & - & $3 \cdot 4$ \\
\hline $\mathrm{C}_{19: 0} 2-\mathrm{OH} \quad 11,12$ & - & - & - & - & - & - & - & - & $21 \cdot 6$ \\
\hline \multicolumn{10}{|l|}{ Unknown: } \\
\hline Unknown $10 \cdot 928$ & $2 \cdot 85$ & - & - & - & - & - & - & - & - \\
\hline $\mathrm{C}_{19: 0}$ 10-methyl & - & - & - & - & - & - & $1 \cdot 1$ & - & - \\
\hline $\mathrm{C}_{19: 0}$ cyclo $\omega 8 c$ & - & - & - & - & $4 \cdot 19$ & $21 \cdot 6$ & - & $4 \cdot 3$ & $10 \cdot 6$ \\
\hline
\end{tabular}

*FAME data from Kämpfer et al. (2003), Han et al. (2003) and Alarico et al. (2002).

Gram-negative cocci, non-motile, red-pigmented by carotenoids, do not contain Bchl $a$, aerobic, facultatively fermentative. Positive for catalase, oxidase and urease but test negative for lysine and ornithine decarboxylases and arginine dihydrolase. Do not hydrolyse cellulose or starch. Contain $\mathrm{C}_{18: 1} \omega 7 \mathrm{c}$ and $\mathrm{C}_{16: 0}$ as the major fatty acids, phosphatidylcholine, phosphatidylglycerol and diphosphatidylglycerol (cardiolipin) as polar lipids and ubiquinone-9 as the respiratory quinone. DNA G $+\mathrm{C}$ content is $75 \mathrm{~mol} \%$. Phylogenetically, a member of the $\alpha-1$ subgroup of the Alphaproteobacteria. The type species is Belnapia moabensis.

\section{Description of Belnapia moabensis sp. nov.}

Belnapia moabensis (mo.a.ben'sis. N.L. gen. n. moabensis of Moab, UT, USA, where the type strain was isolated).
Shows the following properties in addition to those given for the genus. Colonies are convex, round and rough. It grows from 15 to $30^{\circ} \mathrm{C}$, but not at $37^{\circ} \mathrm{C}$, with an optimum growth temperature of $25^{\circ} \mathrm{C}$. The $\mathrm{pH}$ range for growth is $6-8$, with an optimum $\mathrm{pH}$ of 7 . Cannot tolerate $\mathrm{NaCl}$. Cells test negative for lipase, phosphatase, $\beta$-galactosidase, gelatinase, DNase, arginine decarboxylase and phenylalanine deaminase activities. Negative in methyl red, Voges-Proskauer, indole and Simmons' citrate tests. Does not hydrolyse casein, cellulose, aesculin or starch and does not produce $\mathrm{H}_{2} \mathrm{~S}$ gas, but reduces nitrate to nitrite. Cells do not produce acid from D-fructose, L-arabinose, D-galactose, D-glucose, glycerol, D-maltose, D-mannitol, sucrose, D-sorbitol or Dxylose. Ferments L-arabinose, D-galactose, D-maltose and $\mathrm{D}$-xylose but not D-fructose, D-glucose, lactose, sucrose, D-mannose or D-sorbitol. Utilizes adonitol, D-cellobiose, 
glucose, dulcitol, fumaric acid, D-glucose, meso-inositol, inulin, lactose, lactic acid, maltose, D-levulose, D-mannitol, D-mannose, D-raffinose, D-ribose, L-rhamnose, L-sorbose, sucrose, D-sorbitol, D-trehalose, D-xylose, L-aspargine, Lisoleucine, L-methionine, L-proline, L-threonine, L-valine, oxalate and phenanthrene as sole carbon sources but not L-arabinose, acetate, citrate, dextran, ethanolamine, Dfructose, fumaric acid, D-galactose, glycerol, D-melibiose, pyruvate, succinate, L-alanine, L-arginine, L-aspartic acid, L-cysteine, L-glycine, L-glutamine, L-glutamic acid, Lhistidine, L-leucine, L-lysine, L-phenylalanine, L-serine, L-tryptophan, L-tyrosine, adenine, cytosine, guanine, thymidine, nicotinic acid, tartaric acid or indole. Cells are sensitive to carbencillin (100 $\mu \mathrm{g}$ disc), ceftriaxone $(30 \mu \mathrm{g})$, chloramphenicol $(30 \mu \mathrm{g})$, ciprofloxacin $(5 \mu \mathrm{g})$, doxycycline $(30 \mu \mathrm{g})$, erythromycin $(2 \mu \mathrm{g})$, gentamicin $(10 \mu \mathrm{g})$, novobiocin $(30 \mu \mathrm{g})$, penicillin $(10 \mathrm{U})$, rifampicin $(30 \mu \mathrm{g})$, streptomycin $(10 \mu \mathrm{g})$, sulfisoxazole $(300 \mu \mathrm{g})$ and sulfathiazole $(300 \mu \mathrm{g})$, but resistant to aztreonam $(30 \mu \mathrm{g})$, bacitracin $(10 \mathrm{U})$, cephalothin $(30 \mu \mathrm{g})$, colistin $(10 \mu \mathrm{g})$, ethanbutol $(50 \mu \mathrm{g})$, ethionamide $(25 \mu \mathrm{g})$, nitrofurantoin $(150 \mu \mathrm{g})$, polymyxin $\mathrm{B}(300 \mathrm{U})$, tetracycline $(30 \mu \mathrm{g})$, trimethoprim $(5 \mu \mathrm{g})$ and vancomycin $(30 \mu \mathrm{g})$. Methanol extracts of the type strain exhibit absorption maxima at $315,363,465,493$ and $519 \mathrm{~nm}$. Phosphate buffer suspensions $(0 \cdot 1 \mathrm{M}, \mathrm{pH} 7 \cdot 4)$ absorb maximally at 354, 415, 465, 505 and $536 \mathrm{~nm}$.

The type strain, strain CP2C $\mathrm{C}^{\mathrm{T}}\left(=\right.$ ATCC BAA- $1043^{\mathrm{T}}=\mathrm{DSM}$ $\left.16746^{\mathrm{T}}\right)$, was isolated from a BSC in the Colorado Plateau, USA.

\section{Acknowledgements}

This research was funded by the National Science Foundation Biotic Surveys and Inventories grant 0206711 to F. G-P.

\section{References}

Alarico, S., Rainey, F. A., Empadinhas, N., Schumann, P., Nobre, M. F. \& da Costa, M. S. (2002). Rubritepida flocculans gen. nov., sp. nov., a new slightly thermophilic member of the alpha- 1 subclass of the Proteobacteria. Syst Appl Microbiol 25, 198-206.

Belnap, J. (1993). Recovery rates of cryptobiotic crusts: inoculant use and assessment methods. Great Basin Nat 53, 89-95.

Belnap, J. (1994). Potential role of cryptobiotic soil crust in semiarid rangelands. In Proceedings - Ecology and Management of Annual Rangelands, pp. 179-185. Intermountain Research Station, General Technical Report INT-GTR-313. Edited by S. B. Monsen \& S. G. Kitchen. Ogden, UT: USDA Forest Service.

Belnap, J. (2002). Impacts of off road vehicles on nitrogen cycles in biological soilcrusts: resistance in different US deserts. J Arid Environ 52, 155-165.

Belnap, J. \& Gardner, J. S. (1993). Soil microstructure in soils of the Colorado Plateau: the role of the cyanobacterium Microcoleus vaginatus. Great Basin Nat 53, 40-47.

Belnap, J., Büdel, B. \& Lange, O. L. (2001). Biological soil crusts: characteristics and distribution. In Biological Soil Crusts: Structure, Function, and Management, Ecological Studies Series vol. 150, pp. 3-30. Edited by J. Belnap \& O. L. Lange. Berlin: Springer.
Bryantseva, I. A., Gorlenko, V. M., Kompantseva, E. L. \& Imhoff, J. F. (2000). Thioalkalicoccus limnaeus gen. nov., sp. nov., a new alkaliphilic purple sulfur bacterium with bacteriochlorophyll $b$. Int J Syst Evol Microbiol 50, 2157-2163.

Garcia-Pichel, F., Johnson, S. L., Youngkin, D. \& Belnap, J. (2003). Small-scale vertical distribution of bacterial biomass and diversity in biological soil crusts from arid lands in the Colorado plateau. Microb Ecol 46, 312-321.

Han, X. Y., Pham, A. S., Tarrand, J. J., Rolston, K. V., Helsel, L. O. \& Levett, P. N. (2003). Bacteriologic characterization of 36 strains of Roseomonas species and proposal of Roseomonas mucosa sp nov and Roseomonas gilardii subsp rosea subsp nov. Am J Clin Pathol 120, 256-264.

Johnson, S. L., Budinoff, C. R., Belnap, J. \& Garcia-Pichel, F. (2005). Relevance of ammonium oxidation within biological soil crust communities. Environ Microbiol 7, 1-12.

Kämpfer, P., Andersson, M. A., Jackel, U. \& Salkinoja-Salonen, M. (2003). Teichococcus ludipueritiae gen. nov. sp. nov., and Muricoccus roseus gen. nov. sp. nov. representing two new genera of the alpha-1 subclass of the Proteobacteria. Syst Appl Microbiol 26, 23-29.

Kimura, M. (1980). A simple method for estimating evolutionary rates of base substitutions through comparative studies of nucleotide sequences. J Mol Evol 16, 111-120.

Komagata, K. \& Suzuki, K. (1987). Lipid and cell wall analysis in bacterial systematics. Methods Microbiol 19, 161-206.

Kumar, S., Tamura, K., Jakobsen, I. B. \& Nei, M. (2001). MEGA2: molecular evolutionary genetics analysis software. Bioinformatics 17, 1244-1245.

Lanyi, B. (1987). Classical and rapid identification methods for medically important bacteria. Methods Microbiol 19, 1-67.

Nübel, U., Garcia-Pichel, F. \& Muyzer, G. (1997). PCR primers to amplify $16 \mathrm{~S}$ rRNA genes from cyanobacteria. Appl Environ Microbiol 63, 3327-3332.

Reddy, G. S. N. \& Garcia-Pichel, F. (2005). Dyadobacter crusticola sp. nov., from biological soil crusts in the Colorado Plateau, USA, and an emended description of the genus Dyadobacter Chelius and Triplett 2000. Int J Syst Evol Microbiol 55, 1295-1299.

Reddy, G. S. N., Aggarwal, R. K., Matsumoto, G. I. \& Shivaji, S. (2000). Arthrobacter flavus sp. nov., a psychrophilic bacterium isolated from a pond in McMurdo Dry Valley, Antarctica. Int J Syst Evol Microbiol 50, 1553-1561.

Rihs, J. D., Brenner, D. J., Weaver, R. E., Steigerwalt, A. G., Hollis, D. G. \& Yu, V. L. (1993). Roseomonas, a new genus associated with bacteremia and other human infections. J Clin Microbiol 31, 3275-3283.

Saitoh, S. \& Nishimura, Y. (1996). Taxonomic characterization of novel aerobic bacteriochlorophyll-containing bacteria isolated from soil. J Gen Appl Microbiol 42, 121-140.

Saitoh, S., Suzuki, T. \& Nishimura, Y. (1998). Proposal of Craurococcus roseus gen. nov., sp. nov. and Paracraurococcus ruber gen. nov., sp. nov., novel aerobic bacteriochlorophyll $a$-containing bacteria from soil. Int J Syst Bacteriol 48, 1043-1047.

Smibert, R. \& Krieg, N. R. (1994). Phenotypic characterization. In Methods for General and Molecular Bacteriology, pp. 607-654. Edited by P. Gerhardt, R. G. E. Murray, W. A. Wood \& N. R. Krieg. Washington, DC: American Society for Microbiology.

Smith, S. M., Abed, R. M. M. \& Garcia-Pichel, F. (2004). Biological soil crusts of sand dunes in Cape Cod National Seashore, Massachusetts, USA. Microbl Ecol 28, 200-208.

Stackebrandt, E. \& Goebel, B. M. (1994). Taxonomic note: a place for DNA-DNA reassociation and $16 \mathrm{~S}$ rRNA sequence analysis in the present species definition in bacteriology. Int $J$ Syst Bacteriol 44, 846-849. 
Suresh, K., Reddy, G. S. N., Sengupta, S. \& Shivaji, S. (2004). Deinococcus indicus sp. nov., an arsenic-resistant bacterium from an aquifer in West Bengal, India. Int J Syst Evol Microbiol 54, 457-461.

Thompson, J. D., Higgins, D. G. \& Gibson, T. J. (1994). CLUSTAL W: improving the sensitivity of progressive multiple sequence alignment through sequence weighting, position-specific gap penalties and weight matrix choice. Nucleic Acids Res 22, 4673-4680.

Woese, C. R. (1987). Bacterial evolution. Microbiol Rev 51, 221-271. Yoon, J. H., Kang, S. S., Lee, K. C., Lee, E. S., Kho, Y. H., Kang, K. H. \& Park, Y. H. (2001). Planomicrobium koreense gen. nov., sp. nov., a bacterium isolated from the Korean traditional fermented seafood jeotgal, and transfer of Planococcus okeanokoites (Nakagawa et al. 1996) and Planococcus momeekinii (Junge et al. 1998) to the genus Planomicrobium. Int J Syst Evol Microbiol 51, 1511-1520.

Yurkov, V., Stackebrandt, E., Holmes, A. \& 7 other authors (1994). Phylogenetic positions of novel aerobic, bacteriochlorophyll a-containing bacteria and description of Roseococcus thiosulfatophilus gen. nov., sp. nov., Erythromicrobium ramosum gen. nov., sp. nov., and Erythrobacter litoralis sp. nov. Int J Syst Bacteriol 44, 427-434. 